\title{
Separation of Church and State: "New" Directions by the "New" Supreme Court
}

\author{
JESSE H. CHOPER
}

Issues of separation of church and state and freedom of religion have represented one of the most active areas of constitutional adjudication in the United States Supreme Court during the decades of the 1970s and 1980s. Indeed, in the past several years, the Court has made major changes in its approach to every important aspect of the subject. Some of these shifts are more obvious than others, and additional moves are likely to occur in the next few years. This article will explore four general themes revealed in recent decisions and then discuss those themes in the context of the four major areas of constitutional adjudication under the religion clauses of the First Amendment.

\section{Four Emerging Themes in the Supreme Court's TREATMENT OF CHURCH-STATE ISSUES}

First, on a general level, the Supreme Court has moved away from affording religion "special" treatment (either by forbidding it certain benefits or granting it exemption from certain burdens), and has moved toward a position of neutrality (or equality) on church-state issues, attempting to steer a more nonpartisan course between sacred and secular institutions and between religious and nonreligious individuals.

Second, and more specifically, the Court has moved away from the Lemon test ${ }^{1}$ toward two competing approaches. One

- JESSE H. CHOPER (B.S., Wilkes College; LL.B., University of Pennsylvania; D. Hu. Litt., Wilkes College) is currently Dean and Earl Warren Professor of Public Law at the University of California, Berkeley. He is author of Judicial Review and the National Political Process: A Functional Reconsideration of the Role of the Supreme Court, and is coauthor of Constitutional Law: Cases, Comments, and Questions, The American Constitution: Cases and Materials, and The First Amendment: Cases, Comments and Questions, among others. Special thanks go to David T. Owen-Ball of the Boalt Hall Class of 1991 for his exceptionally able assistance. An earlier version of this article was delivered as a lecture at the 1992 J.M. Dawson Institute for Church-State Studies at the Center for Constitutional Studies at Baylor University.

1. Under the Lemon test, which was the prevailing standard for resolving Estab- 
of those approaches - the "endorsement" test - is championed by Justice Sandra Day O'Connor. Initially articulated in the middle 1980s, this test would find an Establishment Clause violation for government "endorsement of religion," which takes place whenever a reasonable observer would conclude that government activity "sends a message to nonadherents that they are outsiders, not full members of the political community, and an accompanying message to adherents that they are insiders, favored members of the political community."2 Of the current members of the United States Supreme Court, this test has the support of the two leading "liberals" remaining, Justices Harry Blackmun and John Paul Stevens. Blackmun is more enthusiastic about the endorsement test than Stevens, but this approach is probably the best that Stevens - who is the strictest separationist on the Court, even more so than were Justices William Brennan and Thurgood Marshall - can probably hope to get.

The other test competing to replace the Lemon test is Justice Anthony Kennedy's "coercion" approach. ${ }^{3}$ The choice of the word "coercion" as the title for this test is probably unfortunate, because Justice Kennedy has defined the term much more broadly than its usual meaning, allowing that coercion may take a variety of "more or less subtle" forms, including "taxation to supply the substantial benefits that would sustain a state-established faith, direct compulsion to observance, or governmental exhortation to religiosity that amounts in fact to proselytizing."4

lishment Clause challenges during the past two decades, government activity must have a secular purpose, its primary effect must neither advance nor inhibit religion, and it must not foster excessive government entanglement with religion; Lemon $v$. Kurtzman, 403 U.S. 602 (1971) at 612-13.

2. Lynch v. Donnelly, 465 U.S. 668 (1984) at 688 (O'Connor, J., concurring). For more extensive elaboration and application of the endorsement test, see Justice O'Connor's concurring opinions in County of Allegheny v. American Civil Liberties Union, 109 S. Ct. 3086 (1989) at 3117-24 and Wallace v. Jaffree, 472 U.S. 38 (1985) at 67-79.

3. This is quite close to this author's approach to Establishment Clause issues. See Jesse H. Choper, "Religion in the Public Schools: A Proposed Constitutional Standard," Minnesota Law Review 47 (1963): 329; Choper, "The Establishment Clause and Aid to Parochial Schools," California Law Review 56 (1968): 260 (hereinafter Aid to Parochial Schools); Choper, "The Religion Clauses of the First Amendment: Reconciling the Conflict," U. Pitt L. Rev. 41 (1980): 673, 675 ("the Establishment Clause should forbid only government action whose purpose is solely religious and that is likely to impair religious freedom by coercing, compromising, or influencing religious beliefs"); emphasis omitted.

4. Allegheny, $109 \mathrm{~S}$. Ct. at 3136 (Kennedy, J., concurring in part and dissenting in part). 
As with the endorsement test, 5 the exact contours of Justice Kennedy's approach remain to be determined. Of the present members of the Court, Chief Justice William $H$. Rehnquist and Justices Byron R. White and Antonin Scalia joined in Justice Kennedy's dissenting opinion in Allegheny County, which contains the fullest exposition of the test. 6 At this writing, Justices David Souter and Clarence Thomas have yet to express their views on the appropriate test.

Those justices committed to the broadly framed Allegheny County version of the coercion test, however, have not always applied it where it would seem dispositive. For example, Justice Scalia, dissenting in Texas Monthly, Inc. v. Bullock (joined by Chief Justice Rehnquist and Justice Kennedy), found "no basis in the text of the Constitution, the decisions of this Court or the traditions of our people" for the Court's decision that a state tax exemption limited to religious publications violated the Establishment Clause. ${ }^{7}$ Justice Scalia made no reference to the coercion principle, taking issue instead with the application of the Lemon test in Justice Brennan's plurality opinion. ${ }^{8}$ Nevertheless, although some would distinguish for these purposes between a government subsidy and a special immunity from taxation, ${ }^{9}$ a tax exemption for religious publications does appear to violate the coercion test by giving "direct benefits to religion" through "subtle coercion ... in the form of taxation."10

Third, the current Supreme Court is less separationist than in the past. In particular, it has become more accommodationist toward the "major" or "mainstream" religions, namely the dominant Judeo-Christian faiths. The fourth theme, which actually is the opposite side of the coin in respect to the third theme, is that the Court has become substantially less protective of "smaller," "nonconforming" religious groups. Both of these final themes may be seen as the product of greater judicial re-

5. Regarding the ambiguity of the endorsement test, see Smith, "Symbols, Perceptions, and Doctrinal Illusions: Establishment Neutrality and the "No Endorsement" Test," 86 Michigan Law Review (1987): 266, 283, 301-03, 310-12; "The Supreme Court, 1988 Term - Leading Cases," Harv. L. Rev. (1989): 137, 235.

6. See also Board of Education v. Mergens, 110 S. Ct. 2356 (1990) at 2377-78(Kennedy, J., concurring).

7. Texas Monthly, Inc. v. Bullock, 109 S. Ct. 890 (1989) at 909.

8. Ibid. at 913-15.

9. See generally Boris Bittker, "Churches, Taxes and the Constitution," Yale Law Journal 78 (1969): 1285; William R. Consedine and Charles M. Whelan, "Church Tax Exemptions," Catholic Law 15 (1969): 93.

10. Allegheny, $109 \mathrm{~S}$. Ct. at 3136 (Kennedy, J., concurring in part and dissenting in part). 
straint on the part of the "new" Supreme Court - an increased willingness to defer to the elected branches of government and a larger reluctance to reject government action in favor of individual rights.

Although generally supportive of the trend toward greater accommodation manifested in the third theme, at least in the absence of any meaningful threat to religious liberty, ${ }^{11}$ this author disagrees with the Court's shrunken protection for smaller religions found in the fourth. In my view, the major role of the Court and the institution of judicial review is to provide protection for those without the numbers and influence to ensure significant and effective protection through the political process, especially when rights specifically posted in the United States Constitution are involved. ${ }^{12}$

\section{The Four Major Areas of Constitutional Adjudication UNDER THE RELIGION CLAUSES}

\section{FREE EXERCISE}

The first theme (neutrality) and the fourth theme (less protection for nonconforming religious groups) were dramatically illustrated by the Court's recent decision in Employment Division, Department of Human Resources v. Smith..$^{13}$ In Smith, Oregon denied unemployment compensation to two drug rehabilitation counselors who were fired from their jobs when it became known that they had ingested peyote, a controlled substance in Oregon, for sacramental purposes at a Native American Church ceremony. The basis for the agency's decision that the drug counselors were ineligible for unemployment benefits was that they had been fired for work-related "misconduct."14 The drug counselors relied upon a line of earlier Supreme Court cases $^{15}$ that had applied the "strict scrutiny" test ${ }^{16}$ to similar de-

11. See Jesse H. Choper, "Church, State and the Supreme Court: Current Controversy," Ariz. L. Rev. 29 (1987): 551.

12. See Jesse H. Choper, Judicial Review and the National Political Process: A Functional Reconsideration of the Role of the Supreme Court (Chicago: University of Chicago Press, 1980).

13. Employment Division, Dept. of Human Resources v. Smith, 110 S. Ct. 1595 (1990).

14. Ibid. at 1598.

15. Sherbert v. Verner, 3774 U.S. 398 (1963); Thomas v. Review Board, Employment Security Division, 450 U.S. 707 (1981); Hobbie v. Unemployment Appeals Commission, 480 U.S. 136 (1987).

16. Under the strict scrutiny test, religious objectors were generally entitled to exemptions from generally applicable laws when "government has placed a sub- 
nials of unemployment compensation to religious objectors, thus establishing the rule that a state "cannot condition the availability of unemployment insurance on an individual's unwillingness to forgo conduct required by his religion."17

Justice Scalia, writing for a majority of five, ${ }^{18}$ expressly appealed to the neutrality theme in holding the strict scrutiny test, and the cases upon which the drug counselors had relied, inapplicable to an "across-the-board criminal prohibition on a particular form of conduct" such as Oregon's listing of peyote as a controlled substance. ${ }^{19}$ "Any society" that required special exemptions for those objecting to generally applicable government regulations on religious grounds would be "courting anarchy" due to the practically unlimited range of regulations that could be subjected to religious challenges. ${ }^{20}$

Smith illustrates theme four, the reduction in the level of Supreme Court protection for nonconforming religions, even more poignantly. The Court expressly conceded that its rejection of constitutionally required exemptions under the Free Exercise Clause would leave adherents of small religions in a more vulnerable position than adherents of "mainstream" faiths: "It may fairly be said that leaving accommodation to the political process will place at a relative disadvantage those religious practices that are not widely engaged in. ..."21 To justify the impact of its holding, the Court reasoned "that unavoidable consequence of democratic government must be preferred to a system in which each conscience is a law unto itself or in which judges weigh the social importance of all laws against the centrality of all religious beliefs."22

stantial burden on the observation of a central religious belief or practice" and no "compelling governmental interest justifies the burden." Hernandez v. Commissioner of Internal Revenue, $109 \mathrm{~S} . \mathrm{Ct} .2136$ (1989) at 2148.

17. Smith, 110 S. Ct. at 1598.

18. Chief Justice Rehnquist and Justices White, Stevens and Kennedy joined in Justice Scalia's majority opinion. Justice O'Connor filed an opinion concurring in the judgment, in parts of which Justices Brennan, Marshall and Blackmun joined without concurring in the judgment. Justice Blackmun filed a dissenting opinion, in which Justices Brennan and Marshall joined. Smith at 1597.

19. Ibid. at 1603 .

20. Ibid. at 1605-06.

21. Ibid. at 1606.

22. Ibid. For the view that this dilemma could be avoided by the use of a limiting principle to narrow the range of claims that can be brought by religious objectors against generally applicable laws, see Jesse H. Choper, "The Rise and Decline of the Constitutional Protection of Religious Liberty," Nebraska Law Review 70 (1991): 651 . 
GOVERNMENT FINANCIAL ASSISTANCE TO RELIGIOUS INSTITUTIONS

This remains the principal area in which the Lemon test, especially its "purpose" and "effect" prongs, has continued to be used. A rough but generally accurate statement of the rule in this area is that it has been permissible for government aid to go to children or their parents who make the private choice to send their children to parochial schools, whereas it is impermissible for the aid to go directly to the parochial schools themselves. ${ }^{23}$

The Court's movement in the direction of neutrality is made evident in Witters v. Department of Services for the Blind ${ }^{24}$ and Bowen v. Kendrick. ${ }^{25}$ Witters involved a Washington program providing vocational rehabilitation assistance in the form of a voucher (although it was not called that) to the visually handicapped that could be used to defray educational costs. The applicant sought to use the aid at a Bible college where he was studying the Bible, ethics, speech, and church administration in preparation for a career as a pastor, missionary, or youth director. ${ }^{26}$ The state denied his application, and the Washington Supreme Court affirmed, applying the Lemon test to find an impermissible effect under the Establishiment Clause: "The provision of financial assistance by the State to enable someone to become a pastor, missionary, or church youth director clearly has the primary effect of advancing religion." 27

The Court reversed, finding no Establishment Clause violation, in a unanimous opinion written by Justice Thurgood Marshall, ordinarily a quite strict separationist. Because the aid went to the student, not to the school, and thus any benefit to the school came as the result of the private choice of the individual recipient, not the government, Justice Marshall found no "primary effect" of advancing religion. ${ }^{28}$ But a majority of the Court had rejected that distinction in Committee for Public Education $v$. Nyquist, ${ }^{29}$ as had Justice Marshall himself in a persuasive dissent in Mueller v. Allen. ${ }^{30}$ In Witters, Justice Marshall

23. Jesse H. Choper, "The Establishment Clause and Aid to Parochial Schools An Update," California Law Review 75 (1987): 5, 13 (hereinafter "Aid to Parochial Schools - Update").

24. Witters v. Dept of Services for the Blind, 474 U.S. 481 (1986).

25. Bowen v. Kendrick, 108 S. Ct. 2562 (1988).

26. Witters, 474 U.S. at 483.

27. Witters v. Commission for the Blind, 102 Wash. 2d 624, 629, 689 P.2d 53, 56 (1984).

28. Witters, 474 U.S. at 75I-52.

29. Public Education v. Nyquist, 413 U.S. 756 (1973) at 781.

30. Mueller v. Allen, 463 U.S. 388 (1983) at 407-08. 
also relied upon the type of empirical approach that the Court had rejected in Mueller" to demonstrate that no "significant portion" of the program's resources would "end up flowing to religious education." 32

More importantly, an analysis of the concurring opinions in Witters demonstrates that a majority of the Court - the same justices who comprised the majority in Mueller v. Allen would have found a broad state program providing parents with vouchers to be constitutional. ${ }^{33}$ Justice Lewis F. Powell (joined by Chief Justice Warren Burger and (then) Justice Rehnquist) emphasized, citing Mueller, that "state programs that are wholly neutral in offering educational assistance to a class defined without reference to religion do not violate the second part of the Lemon v. Kurtzman test, because any aid to religion results from the private choices of individual beneficiaries." ${ }^{34}$ Justices White and O'Connor wrote separate opinions agreeing with Justice Powell with respect to the significance of Mueller. ${ }^{35}$ Therefore, a voucher program providing aid to all parents who have children in schools, whether public, private or parochial, is - since Witters - constitutionally valid.

Moreover, even though there has been no formal opinion of the Court on financial assistance to religious schools since the departure of Justice Powell, who championed the existing rough distinction between aid to parents and aid to the schools themselves, the separate opinion of Justices Kennedy and Scalia in Bowen v. Kendrick indicates that there are now at least five votes for upholding direct government assistance to religious elementary and secondary schools.

Bowen v. Kendrick involved a challenge to the Adolescent Family Life Act (AFLA), ${ }^{36}$ a federal statute providing funding for adolescent sexuality and pregnancy services and expressly authorizing participation by religious organizations. In an opinion written by Chief Justice Rehnquist, the Court first found that the statute's authorization of participation by religious organizations along with various other types of community organizations maintained "a course of neutrality among religions, and

31. Ibid. at 401 .

32. Witters, 474 U.S. at 752.

33. Choper, "Aid to Parochial Schools - Update," 13 (Chief Justice Burger and Justices Powell, Rehnquist, White and O'Connor).

34. Witters, 474 U.S. at $490-91$ (citation omitted).

35. Ibid. at 490 (White, J., concurring); ibid. at 493 (O'Connor, J., concurring).

36. 42 U.S. Code $\$ \$ 300 z$. 
between religion and non-religion," and therefore did not violate the "effect" prong of the Lemon test. ${ }^{37}$ Second, direct receipt of federal funds by such religious organizations would not violate the effect prong in the absence of a showing of a "substantial' risk that aid to these religious institutions would, knowingly or unknowingly, result in religious indoctrination."38 Finally, the Court held that since "there is no reason to assume that the religious organizations which may receive grants are 'pervasively sectarian' in the same sense as the Court has held parochial schools to be," there is no reason to fear excessive government entanglement (the Lemon test's third prong) in the form of unduly intrusive monitoring of "the day-to-day operation of the religiously affiliated AFLA grantees." 39

It is the concurring opinion of Justice Kennedy, joined by Justice Scalia, however, that is most significant for future challenges to programs providing government financial assistance to religious schools. Justice Kennedy took the position that "the only purpose of further inquiring whether any particular grantee institution is pervasively sectarian is as a preliminary step to demonstrating that the funds are in fact being used to further religion."40 A statutory program that distributes program benefits "in a neutral fashion to religious and nonreligious applicants alike" should not be found unconstitutional simply because specific recipients of government funds are religious in character. ${ }^{41}$ Ultimately, the question "is not whether the entity is of a religious character, but how it spends its grant." 42

The view of Justices Kennedy and Scalia, along with the position taken by Chief Justice Rehnquist and Justices White and O'Connor in earlier cases involving aid to parochial schools, ${ }^{43}$ makes five votes among the current members of the Court (apart from any consideration of the positions that Justices Souter and Thomas might take) for an approach emphasizing the

37. Bowen v. Kendrick, $108 \mathrm{~S}$. Ct. at 2573 (quoting Grand Rapids School District v. Ball, 473 U.S. 373 (1985) at 382).

38. Ibid. at 2576 .

39. Ibid. at 2578 .

40. Bowen, $108 \mathrm{~S}$. Ct. at 2582 (Kennedy, J., concurring).

41. Ibid.

42. Ibid. (emphasis added).

43. See, e.g., Commission for Public Education and Religious Liberty v. Nyquist, 413 U.S. 756 (1973) at 812-13 (Rehnquist, J., dissenting, joined by Burger, C.J., and White, J.); Wolman v. Walter, 433 U.S. 229 (1977) at 255 (White and Rehnquist, JJ., concurring in part and dissenting in part); Grand Rapids v. Ball, 473 U.S. 373 (1985) at 398 (O'Connor, J., concurring in part and dissenting in part); ibid. at 400 (Rehnquist, J., dissenting); ibid. (White, J., dissenting). 
use to which religious organizations put government financial assistance, rather than the religious nature of the recipient institutions. ${ }^{44}$ The author's prediction is that the Court will adopt this approach the next time that it has an appropriate opportunity to consider the issue.

In addition, Bowen v. Kendrick illustrates theme three, the Court's greater accommodation of "mainstream" religions, because it is mainly these kinds of religious organizations that are large enough to engage in activities such as sponsoring family planning services and operating parochial schools.

\section{RELIGION IN PUBLIC SCHOOLS}

The key recent decision in this area is Board of Education $v$. Mergens, ${ }^{45}$ which, like Bowen $v$. Kendrick, strongly illustrates the themes of neutrality and accommodation of mainstream religions, as well as the newer competing Establishment Clause approaches found in theme two. Mergens involved an Establishment Clause review of the Equal Access Act, ${ }^{46}$ in which Congress has prohibited public secondary schools that receive federal funds and that maintain a "limited open forum" which exists whenever the school permits "noncurriculum related student groups to meet on school premises during noninstructional time" 47 - from denying "equal access" on the basis of the content of the speech at such meetings. ${ }^{48}$

Mergens was brought by public high school students whose request for permission to form a Christian club at the school was denied. The students sought to meet on the same terms as other student groups, except that the proposed club would not have had a faculty sponsor. Membership would have been voluntary and open to all students regardless of religious affliation. ${ }^{49}$

Justice O'Connor delivered the opinion of the Court on issues of statutory interpretation, but only Chief Justice Rehnquist and Justices White and Blackmun joined her plurality Establishment Clause analysis. Justices Kennedy and Scalia and Justices

44. This is consistent with this author's approach that government aid to parochial schools is constitutionally valid as long as the government receives in return an equivalent or greater value in terms of "the secular educational service rendered." Choper, "Aid to Parochial Schools," 316; Choper, "Aid to Parochial Schools - Update," 14.

45. Board of Education v. Mergens, 110 S. Ct. 2356 (1990).

46. 20 U.S. Code $\$ \$ 4071-74$.

47. 42 U.S. Code $\$ 4071(\mathrm{~b})$.

48. 20 U.S. Code $\$ 4071(a)$.

49. Mergens, $110 \mathrm{~S}$. Ct. at 2363. 
Marshall and Brennan filed concurring opinions addressing the constitutional question.

The opinions of Justices O'Connor and Kennedy, upholding the constitutionality of the Equal Access Act, both underline the first theme of neutrality and the third theme of accommodation. ${ }^{50}$ Both justices also amplify their competing Establishment Clause approaches in Mergens.

The school had argued that the Act would require it "effectively [to] incorporate religious activities into the school's official program," thus "endors[ing] participation in the religious club, and provid[ing] the club with an official platform to proselytize other students." 51 In response, Justice O'Connor distinguished between "government speech endorsing religion, which the Establishment Clause forbids, and private speech endorsing religion, which the Free Speech and Free Exercise Clauses protect."52 Based on that distinction, Justice O'Connor found no governmental "endorsement" of religion because "secondary school students are mature enough and are likely to understand that a school does not endorse or support student speech that it merely permits on a nondiscriminatory basis." 53

As for Justice Kennedy's principle " that the government cannot coerce any student to participate in a religious activity,"54 Justice Kennedy found that the Act "does not authorize school authorities to require, or even to encourage, students to become members of a religious club or to attend a club's meetings, ... the meetings take place while school is not in session, .... and the Act does not compel any school employee to participate in, or to attend, a club's meetings or activities." 55 Justice Kennedy did acknowledge that the coercion inquiry "must be undertaken with sensitivity" to its more subtle forms, but found no indication of any subtle pressure to participate in the club. ${ }^{56}$

Justice Kennedy criticized Justice O'Connor's endorsement test, however, on the ground that " $[t]$ he word endorsement has insufficient content to be dispositive." 57 To illustrate, in

50. Ibid. at 2371 (O'Connor, J.); ibid. at 2377 (Kennedy, J., concurring).

51. Ibid. at 2370 .

52. Ibid. at $\mathbf{2 3 7 2}$.

53. Ibid.

54. Ibid. (citations to Justice Kennedy's separate opinions in Allegheny County and Lynch v. Donnelly omitted).

55. Ibid.

56. Ibid. at 2378 .

57. Ibid. 
Mergens, Justice Kennedy would have reached the opposite result under the endorsement test: "I should think it inevitable that a public high school "endorses" a religious club, in a common-sense use of the term, if the club happens to be one of many activities that the school permits students to choose in order to further the development of their intellect and character in an extracurricular setting." 58

The extent to which the movement toward neutrality or equality of access that is evidenced in Mergens will affect other religion-in-the-public-schools practices remains to be seen. The contrasting approaches of Justices O'Connor and Kennedy, however, promise to have special significance as the Court deals with these issues in the future. For example, the constitutionality of religious instruction on school premises during "released time," which has been invalid since 1948,59 might hinge - for both Justices O'Connor and Kennedy (and those who subscribe to their positions) - upon the breadth of the range of alternatives offered to students under such a program. ${ }^{60}$ Regarding prayer or Bible reading in public schools, ${ }^{61}$ it is possible to speculate that Justice O'Connor may prove to be less of a separationist than Justice Kennedy. If a school were to institute a program of opening each school day with a reading from a wide variety of materials - say, some version of the Bible on Monday, an historically famous speech on Tuesday, a selection from great literature on Wednesday, etc. - that might be enough for Justice O'Connor to find no "endorsement." By contrast, this should theoretically make no difference under Justice Kennedy's approach. Since only Bible-reading would take place on some days, "coercion" to participate in a religious exercise would then occur. The posting of the Ten Commandments in a public classroom would be a much closer question under Justice Kennedy's coercion approach than it was for the Court a decade ago, ${ }^{62}$ while Justice O'Connor might more readily find it to be an en-

\footnotetext{
58. Ibid.

59. McCollum v. Board of Education, 333 U.S. 203 (1948).

60. For discussion of the constitutionality of on-site programs allowing instruction in religion in addition to other subjects after Widmar v. Vincent, 454 U.S. 263 (1981), and Mergens, see Douglas Laycock, "Equal Access and Moments of Silence: The Equal Status of Religious Speech by Private Speakers," Northwestern University Law Review 81 (1986): 1, 33-35.

61. See, e.g., Engel v. Vitale, 370 U.S. 421 (1962) (nondenominational theistic prayer); Abington School District v. Schempp, 374 U.S. 203 (1963) (Bible reading and recitation of Lord's Prayer).
}

62. See Stone v. Graham, 449 U.S. 39 (1980). 
dorsement. As for the observance of a moment of silence ${ }^{63}$ or the teaching of "creation science,"64 Justice O'Connor could well find such practices to constitute endorsement, ${ }^{65}$ whereas it is doubtful that Justice Kennedy would find them to be coercive.

\section{GOVERNMENT ACKNOWLEDGMENT OF RELIGION}

This area is composed entirely of fairly recent decisions. In three cases during the past decade, the Court has upheld government acknowledgments of religion. First, in Marsh v. Chambers, ${ }^{66}$ the Court sustained the Nebraska legislature's practice of opening each session with prayer by a government-paid chaplain. Next, in Lynch v. Donnelly, ${ }^{67}$ the Court upheld the city of Pawtucket's inclusion of a nativity scene as a part of a larger Christmas display in a city park. Finally, in County of Allegheny v. American Civil Liberties Union,68 the Court affirmed the display of a menorah along with a Christmas tree near the entrance to an office building owned by the City of Pittsburgh and Allegheny County.

Each of these decisions illustrates the third theme: the Court's tendency to be less separationist and more accommodating of mainstream religions. The Court's rationale in these three cases varied - from a focus on history and original intent in Marsh v. Chambers, ${ }^{69}$ to finding a secular purpose for the display in Lynch $v$. Donnelly, ${ }^{70}$ to reasoning that the display of the menorah did not constitute an endorsement of Judaism in Allegheny County. ${ }^{71}$ In the main, however, the Court's actions make clear that there are various types of public government acknowledgments of religion that do not violate the Establishment Clause; i.e., no strict separation between government and religion is required.

The one exception to this trend took place in Allegheny County, where the Court found the display of a creche - standing alone - in the county courthouse to represent a govern-

63. See Wallace v. Jaffree, 472 U.S. 38 (1985).

64. See Edwards v. Aguillard, 482 U.S. 578 (1987).

65. As Justice O'Connor did for Alabama's program in Jaffree (472 U.S. at 78-79)

and Louisiana's requirement in Aguillard (482 U.S. at 593).

66. Marsh v. Chambers, 463 U.S. 783 (1983).

67. Lynch, 465 U.S. 668 (1984).

68. Allegheny, 109 S. Ct. 3086 (1989).

69. Marsh, 463 U.S. at 3333-36.

70. Lynch, 465 U.S. at $680-81$.

71. Allegheny, $109 \mathrm{~S}$. Ct. at 3112. 
ment endorsement of religion. ${ }^{72}$ The vote was five to four, but two of those in the majority - Justices Brennan and Marshall are now retired. Four justices dissented in an opinion written by Justice Kennedy and applying his Establishment Clause approach. ${ }^{73}$ If just one of the two newest members of the Court either Justice Souter or Justice Thomas - joins the Kennedy group, then the outcome would be different in a similar case.

\section{CONCLUSION}

In this author's view, all church-state problems (including government-acknowledgment-of-religion issues) should be resolved by recourse to a broad principle that accounts for the major function of the Establishment Clause (as well as the Free Exercise Clause): protection of religious liberty. The Court should permit accommodations of religion under the Establishment Clause and require exemptions for religious objectors under the Free Exercise Clause when no meaningful threat to individual religious freedom can be said to exist. It should be of no consequence that such accommodations or exemptions mean that the government is acting with a religious purpose, nor that they may be perceived by reasonable observers as constituting symbolic endorsements of religion. Along with Justice Kennedy, the showing of a real threat to religious liberty would be required rather than a shadow. That someone may take offense at government acknowledgment of religion, or religious exemptions from generally applicable laws, or that strife may occur along religious lines whether the government erects (or refrains from erecting) a holiday display that includes religious symbols should not be determinative.

72. Allegheny, $109 \mathrm{~S}$. Ct. at 3104-05.

73. Allegheny, $109 \mathrm{~S}$. Ct. at 3136-40. See text at notes 4-6. 
Book REVIEWS JCS 


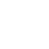

